\title{
$\mathrm{LCA}$ 개념을 도입한 학교시설 녹색건축인증기준 개선방향에 관한 연구
}

\section{A Study on the Improvement of the School Green Building Certification System based on Life Cycle Assessment Methodology}

\author{
이 재 옥* \\ Lee, Jae-Ok \\ 김 성 중** \\ Kim, Sung-Joong \\ 이 상 민 ${ }^{* * *}$ \\ Lee, Sang-Min \\ 이 승 민 ${ }^{* * *}$ \\ Lee, Seung-Min
}

\begin{abstract}
The purpose of this study is to suggest the way how to improve the school green building certification system based on life cycle assessment methodology and to assess $\mathrm{LCCO}_{2}$ in outline.

Green Building Certification System for School is comprised of 7 categories and 39 items. 7 categories include Land use and Transport, Energy and Atmosphere, Materials and Resources, Water, Management, Ecology, Indoor environmental quality.

School is a public facility for students. So Green Building Certification System for School must have educational point of view adding to energy saving, reduction of greenhouse gas emission, etc. Also it needs to be classified into three categories ; kindergarten, elementar/middl/high school and university.

Improvement plans for items are as follows ; energy consumption and $\mathrm{LCCO}_{2}$ assessment considering life cycle, deletion or integration of duplicate items by comparing other systems, application of passive solar systems, consideration of the law and standards change, and selection of items considering specific building use.
\end{abstract}

키워드 : LCA, 학교시설, 녹색건축인증기준

Keywords : Life Cycle Assessment, School, Green Building Certification System

\section{1. 서론}

\section{1 연구의 배경과 목적}

건축물의 생애주기를 고려한 에너지소비량 절감과 이산 화탄소 배출 절감은 전 세계가 당면한 과제이며, 이러한 문제해결을 위한 노력의 일환으로 미국, 영국, 일본 등에 서는 각 국가의 실정에 맞는 녹색건축물 인증제도를 마련 하여 시행하고 있다. 우리나라도 2002년부터 친환경건축물 인증제도를 시행하고 있으며, 2013년 2월 23일부터 '녹색

* 정회원, (사)한국교육환경연구원 녹색건축센터장

** 정회원, (사)한국교육환경연구원 기획관리국장

*** 정회원, (사)한국교육환경연구원 연구본부장

**** 정회원, (사)한국교육환경연구원 연구부장, 교신저자 (smlee01@hanmail.net)

본 연구는 국토해양부 첨단도시개발사업의 연구비지원(12CHUDC060349-02-000000)에 의해 수행되었습니다.
건축물 조성지원법’이 시행되면서 '녹색건축 인증제도'라는 새로운 명칭을 사용하고 전반적인 개정작업을 시작하였다. 국내 인증제도 시행초기에는 인증실적이 저조하였으나 인 센티브 마련, 친환경건축물에 대한 인식 확대, 인증기준 개정, 인증대상 확대 등을 통해 2012년 12월말 기준으로 3,199 건의 예비인증 및 본인증 실적을 나타내었다. 그 중 학교시설이 1,275 건으로 약 $40 \%$ 를 차지하고 공동주택이 1,127 건으로 약 $35 \%$ 를 차지하고 있어, 2002년에 시행된 공 동주택 인증기준에 비해 학교시설 인증기준은 2005년에 시행된 것을 감안할 때 학교시설의 친환경화 확산속도를 짐작할 수 있다.

학교시설의 경우 학생들의 교육을 위해 사용하는 공간 으로 사회적 공공성이 매우 강한 건축물이라는 특수성을 반영할 뿐만 아니라 법률 및 기준변경 고려, 건축물의 친 환경 수준 향상, 학교급별 특성 등을 고려하여 녹색학교의 
양적증가 뿐만 아니라 질적향상을 꾀할 필요가 있다.

기존의 건축물 $\mathrm{LCA}$ 평가 관련 연구는 $\mathrm{LCCO}_{2}$ 배출량을 산출하는 방법론에 관한 것이 대부분이며 한국건설기술연 구원에서 연구한 건축물 $\mathrm{LCA}$ 를 위한 원단위 작성 및 프 로그램 개발연구(2004)의 경우 LCA기법에 의해 평가 혹 은 대체가 가능한 평가항목을 도출하였으나 학교시설과 관련된 구체적이고 실질적인 $\mathrm{LCA}$ 평가항목의 도출에 대 한 연구성과는 없는 실정으로 본 연구에서는 국내외 녹색 건축물 인증제도 및 평가항목의 비교, 분석을 통해 LCA 개념을 도입한 학교시설 녹색건축인증기준의 개정방향을 모색하고자 한다.

\section{2 연구의 방법 및 절차}

본 연구에서는 LCA개념을 도입한 학교시설 녹색건축물 인증제도의 개선방향 제안을 위해 첫째, 녹색학교의 개념, LCA 개념 및 방법론을 재정립하였다. 둘째, 국내외 녹색건 축물 인증기준의 현황파악 및 평가항목을 비교분석하였다. 셋째, LCA 개략평가를 위한 평가범위, 평가방법을 설정하고 $\mathrm{LCA}$ 평가항목 및 기타 개정 필요한 평가항목을 제안하였다. 국내 인증기준은 2013년 1월 16일 입법예고된 학교시설 인증기준, 국외 인증기준은 미국의 LEED2009, 영국의 BREEAM2011, 일본의 CASBEE2010, 호주의 GREEN STAR (Education), SBTool2012, 홍콩의 BEAM Plus NB 1.2를 대상으로 분석하였다.

\section{2. 녹색학교의 개념 및 건축물의 LCA 개요}

\section{1 녹색학교의 개념 및 학교시설의 특성}

녹색건축물은 에너지이용 효율 및 신·재생에너지의 사 용비율이 높고 온실가스 배출을 최소화하는 건축물1)로 정 의되고 있다. 그리고 녹색건축물 조성의 기본원칙은 온실 가스 배출량 감축, 환경친화적이고 지속가능, 신재생에너 지 활용 및 자원절약, 기존건축물의 에너지효율화, 계층간 및 지역간 균형성 확보이다.2)

녹색학교는 이러한 녹색건축물의 개념이 적용된 학교시 설로 친환경학교, 생태학교, 에코스쿨, 그린스쿨, 지속가능 한 학교 등 여러 가지 용어로 사용되고 있다. 녹색학교는 환경적, 물리적 요소와 운영 및 활용요소로 구분할 수 있 으며, 환경을 고려한 배치계획, 신재생에너지 이용, 자연광 의 이용, 환경친화적인 재료와 공법의 사용, 수자원의 보

\footnotetext{
1) 저탄소녹색성장기본법 제 54 조(녹색건축물의 확대)

2) 녹색건축물 조성지원법 제3조(기본원칙)
}

존, 옥내외 녹지공간 조성 등이 도입된 학교이다.3)

학교시설은 교육의 목적을 효과적, 능률적으로 달성하기 위해 설치한 물리적 환경을 총칭하는 것으로 단순히 교사 와 학생을 수용하는 건축물만을 지칭하는 것은 아니며 학 교전체가 교육의 매체이자 도구이면서 학생의 성장과 발 달을 촉진하는 생활환경을 포괄하는 개념이라고 할 수 있 다.4)따라서 녹색건축 인증기준 설정시 일반건축물과 달리 건축물의 물리적 조건 뿐만 아니라 교육적 효과를 고려한 기능적 특성이 고려되어야 한다.

\section{2 건축물의 $\mathrm{LCA}$}

\section{가) 건축물 $\mathrm{LCA}$ 의 정의}

건축물에 있어 LCA(Life Cycle Assessment)는 자원의 채취단계에서부터 건설자재의 생산, 자재의 수송단계, 건 축물의 시공단계, 사용유지단계, 해체 및 폐기단계에 이르 기까지 건축물의 전생애주기와 관련된 환경부하와 잠재적 환경영향을 투입물과 산출물의 목록화 및 영향평가, 결과 의 해석 등을 통해 파악하는 일련의 과정으로 볼 수 있 다.5) $\mathrm{LCA}$ 는 $\mathrm{CO}_{2}$ 를 포함한 6대 온실가스 및 기타 오염물 질을 대상으로 하고 있으나, 본 연구에서는 $\mathrm{LCA}$ 를 $\mathrm{CO}_{2}$ 배출량으로 범위를 한정하여 검토하도록 한다.

나) 건축물 $\mathrm{LCA}$ 의 평가방법

$\mathrm{LCA}$ 평가방법은 개별적산방법과 산업연관분석법이 있 다. 개별적산방법은 설계도서, 견적서 등으로부터 제조공 정, 소재 등으로 구분하여 각각의 제품이 어떻게 제조되어 폐기되는지를 제품마다 조사하는 방법으로 주로 제품의 $\mathrm{LCA}$ 에 이용된다. 그리고 산업연관분석법은 각 산업에서 생산된 재화 및 서비스가 다른 산업의 생산을 위한 원재 료로 투입되는 산업 간의 상호 연관관계를 수량적으로 평 가하고자 하는 분석방법으로 환경부하를 종합적으로 파악 할수 있고 계산시간이 짧은 장점을 가진다.

다) 건축물 $\mathrm{LCA}$ 평가

건축물의 $\mathrm{LCA}$ 평가시 건축물의 전생애는 건설단계, 운 용단계, 철거단계로 구분된다. 건설단계는 건축자재 생산, 운송, 시공단계로 구분되고, 운용단계는 운영에너지 사용, 유지관리 단계로 구분된다. 그리고 철거단계는 해체 및 폐 기단계로 구분된다. 각 단계별 에너지 소비량 및 자재물량

3) 이호진, 학교건축계획, (사)한국교육환경연구원, 2009, p.239

4) 남정걸, 교육행정 및 교육경영, 서울:교육과학사, 2012, p.362 363

5) 차기욱, $\mathrm{LCA}$ 기반에 의한 건설폐기물 종류별 $\mathrm{CO}_{2}$ 발생량 산출 과 환경비용 산정에 관한 연구, 경북대학교대학원 석사논문, 2011. 
Table 1. Evaluation stage and method of LCA

\begin{tabular}{|c|c|c|}
\hline \multicolumn{2}{|c|}{ 평가단계 } & 평가방법 \\
\hline \multirow{5}{*}{$\begin{array}{l}\text { 건설 } \\
\text { 단계 }\end{array}$} & $\begin{array}{l}\text { 건축자재 } \\
\text { 생산단계 }\end{array}$ & 투입자재물량×단위환산×자재별 $\mathrm{CO}_{2}$ 원단위 \\
\hline & 건축자재 & 자재운반에 필요한 에너지사용량 $\times$ 에너지원별 \\
\hline & 운송단계 & $\mathrm{CO}_{2}$ 원단위 \\
\hline & 건축자재 & 건설장비 사용에 필요한 에너지사용량×에너지 \\
\hline & 시공단계 & 원별 $\mathrm{CO}_{2}$ 원단위 \\
\hline \multirow{2}{*}{$\begin{array}{l}\text { 운용 } \\
\text { 단계 }\end{array}$} & $\begin{array}{l}\text { 에너지 } \\
\text { 사용 }\end{array}$ & $\begin{array}{l}\text { 운영에너지 사용량×에너지원별 } \mathrm{CO}_{2} \text { 원단위 } \\
\text { (시재생에너지 포함) }\end{array}$ \\
\hline & 유지관리 & $\begin{array}{l}\text { 수선·보수가 요구되는 자재물량×단위환산×자 } \\
\text { 재별 } \mathrm{CO}_{2} \text { 원단위 }\end{array}$ \\
\hline \multirow{2}{*}{$\begin{array}{l}\text { 철거 } \\
\text { 단계 }\end{array}$} & 해체단계 & $\begin{array}{l}\text { 건설폐기물발생량×단위무게당 에너지소비량× } \\
\text { 에너지원별 } \mathrm{CO}_{2} \text { 원단위 }\end{array}$ \\
\hline & 폐기단계 & $\begin{array}{l}\text { 건설폐기물 운반에 필요한 에너지사용량×에너 } \\
\text { 지원별 } \mathrm{CO}_{2} \text { 원단위 }\end{array}$ \\
\hline
\end{tabular}

에 대한 에너지원별 혹은 자재별 $\mathrm{CO}_{2}$ 원단위를 이용하여 산출되며, 평가단계별 평가방법은 <표 1>과 같다.6)

위의 일반적인 평가단계 이외에 수자원 및 생활폐기물 에 의한 $\mathrm{CO}_{2}$ 배출량을 고려하고, 그 양이 상대적으로 작기 는 하나 수목에 의한 탄소상쇄량도 고려할 필요가 있다.

본 연구에서는 녹색건축인증제도의 취지를 고려하여 전 체 $\mathrm{CO}_{2}$ 배출량에서 차지하는 비중 및 평가타당성 등을 고 려하여 학교시설의 LCA평가에 중요하게 고려해야 할 평 가항목 설정방향을 제시하고자 한다.

\section{3 국내외 녹색건축인증제도 개요}

녹색건축 인증제도는 건축물의 에너지 및 자원의 절약, 오염물질 배출감소, 주변 환경과의 조화, 건강 및 쾌적 등 환경에 미치는 요인을 평가하여 건축물의 친환경성을 인 증해주는 프로그램이다.

미국, 영국, 일본 등 여러 국가에서는 각 국가의 실정에 맞는 인증기준을 개발하여 시행하고 있으며, 우리나라도 2002년에 친환경건축물 인증제도를 도입하여 건물용도 대
상범위를 순차적으로 확대하였다.

<표 2>는 국내 녹색건축 인증제도를 포함하여 7 개 인 증제도에 대한 개요를 나타낸 것이며, 모두 학교시설에 대 해 별도로 언급하고 학교특성을 고려한 평가항목을 포함 하고 있다. 또한 미국의 LEED는 현재 2009버전이 사용되 고 있으며 새로운 v4 버전에 대한 개정작업이 진행중에 있다. v4 버전에 대해서는 평가항목(안)이 제시되어있으나 구체적인 평가방법이 제시되지 않았다. 따라서 개요 및 전 반적인 평가항목 비교시 2009버전을 이용하고 LCA 관련 항목 분석시 v4 버전을 함께 검토하도록 한다.

\section{3. 국내외 학교시설 녹색건축 인증기준의 평가항 목 비교분석}

국내외 학교시설 녹색건축 인증기준의 평가항목을 비교 분석 하기 위해 현재 국내에서 사용하고 있는 7 개 평가분 야(토지이용 및 교통, 에너지 및 환경부하, 재료 및 자원, 물순환관리, 유지관리, 생태환경, 실내환경)를 기준으로 외 국 인증기준의 평가항목을 재분류하였다.

\section{1 국내외 학교시설 인증기준 공통항목}

국내외 7 개 학교시설 인증기준의 평가항목을 비교하여 5 개 이상 기준에서 공통으로 포함하고 있는 항목을 검토 하여 <표 3>에 정리하였다.

국내외 학교시설 인증기준에서 공통적으로 포함하고 있 는 평가항목은 23개 항목으로, 토지이용 및 교통, 에너지 및 환경부하, 실내환경 분야에서 많은 공통항목을 포함하 고 있다. 그리고 기존대지의 생태학적 가치, 물사용량 절 감, 실내공기질 항목은 7 개 기준 모두에서 평가하고 있는 공통항목이다. 23 개 항목 중 국내 기준에서 평가하고 있지 않는 항목은 주차용량제한, 빛공해 저감, $\mathrm{LCCO}_{2}$ 평가, 건

Table 2. Outline of domestic and foreign green building certification system

\begin{tabular}{|c|c|c|c|c|c|c|c|}
\hline 구분 & 우리나라 & $\begin{array}{c}\text { 미국 } \\
\text { LEED } 2009 \\
\end{array}$ & $\begin{array}{c}\text { 영국 } \\
\text { BREEAM2011 } \\
\end{array}$ & $\begin{array}{c}\text { 일본 } \\
\text { CASBEE2010 } \\
\end{array}$ & 호주 Green Star & SBTool2012 & $\begin{array}{c}\text { 홍콩BEAM } \\
\text { NB } 1.2 \\
\end{array}$ \\
\hline 개발자 & $\begin{array}{l}\text { 국토해양부, } \\
\text { 환경부 }\end{array}$ & $\begin{array}{c}\text { 미국그린빌딩 } \\
\text { 협의회(USGBC) }\end{array}$ & $\begin{array}{l}\text { 건축연구소 } \\
\text { (BRE) }\end{array}$ & 국토교통성 & $\begin{array}{l}\text { 호주그린빌딩 } \\
\text { 협의회(GBCA) }\end{array}$ & $\begin{array}{c}\text { GBC } \\
\text { (Green Building } \\
\text { Challenge) } \\
\end{array}$ & $\begin{array}{c}\text { 홍콩그린빌딩협의회 } \\
\text { (HKGBC) }\end{array}$ \\
\hline 개발연도 & 2002년 & 1997년 & 1990년 & 2002년 & 2003년 & 1998년 & 2010년 \\
\hline $\begin{array}{l}\text { 건물용도 } \\
\text { 구분 }\end{array}$ & $\begin{array}{l}\text { 공동주택, 소형주 } \\
\text { 택, 업무용, 복합건 } \\
\text { 축물 주거, 학교, } \\
\text { 판매시설, 숙박시 } \\
\text { 설, 그밖의건축물 }\end{array}$ & $\begin{array}{l}\text { 문화집회시설, 호 } \\
\text { 텔, 판매시설, 주 } \\
\text { 거시설, 학교, 단 } \\
\text { 독주택, 다가구주 } \\
\text { 택, 병원 및 의료 } \\
\text { 시설 }\end{array}$ & $\begin{array}{l}\text { 상업 건 물 (업 무, } \\
\text { 산업, 판매), 공공 } \\
\text { 건 물(교 육시 설, } \\
\text { 의료시설, 감옥, } \\
\text { 법원), 복합주거, } \\
\text { 그밖 }\end{array}$ & $\begin{array}{l}\text { 비주거(업무시설, } \\
\text { 학교, 판매시설, } \\
\text { 식당, 강당, 공장), } \\
\text { 주거(병원, 호텔, } \\
\text { 아파트) }\end{array}$ & $\begin{array}{l}\text { 공공건물, 산업건 } \\
\text { 물, 교육시설, 병 } \\
\text { 원, 컨벤션센터, 판 } \\
\text { 매시설, 공동주택, } \\
\text { 업무용건물 }\end{array}$ & $\begin{array}{l}\text { 단독주택, 호텔, 도 } \\
\text { 서관, 업무용건축 } \\
\text { 물, 학교, 식당, 소 } \\
\text { 매점, 슈퍼마켓, 쇼 } \\
\text { 핑센터, 극장, 로비 } \\
\text { 및 주차장 }\end{array}$ & $\begin{array}{l}\text { 주거, 상업건물, 산업 } \\
\text { 건물 등 모든 용도 건 } \\
\text { 물 }\end{array}$ \\
\hline
\end{tabular}

6) 김태형 외 1 인, 철근 콘크리트 건축물의 $\mathrm{LCA}$ 평가에 관한 기

초적 연구, 대한건축학회논문집, 2009. 4. 
$\mathrm{LCA}$ 개념을 도입한 학교시설 녹색건축인증기준 개선방향에 관한 연구

Table 3. Common items of domestic and foreign green building certification criteria for schoo

\begin{tabular}{|c|c|c|c|}
\hline 분야 & 평가항목 & $\begin{array}{l}\text { 항목포함 } \\
\text { 기준 수 }\end{array}$ & $\begin{array}{l}\text { 국내기준 } \\
\text { 포함여부 }\end{array}$ \\
\hline \multirow{5}{*}{$\begin{array}{l}\text { 토지이용 } \\
\text { 및 교통 }\end{array}$} & 기존대지의 생태학적 가치 & 7개 기준 & ○ \\
\hline & 대중교통에의 근접성 & 5 개 기준 & O \\
\hline & 자전거보관소 & 6 개 기준 & O \\
\hline & 주차용량 제한 & 5 개 기준 & $\times$ \\
\hline & 빛공해 저감 & 6 개 기준 & $\times$ \\
\hline \multirow{6}{*}{$\begin{array}{l}\text { 에너지 및 } \\
\text { 환경부하 }\end{array}$} & 에너지 성능 & 5 개 기준 & 0 \\
\hline & 모니터링 & 6 개 기준 & O \\
\hline & 조명에너지 절약 & 6 개 기준 & 0 \\
\hline & 신재생에너지 이용 & 5 개 기준 & 0 \\
\hline & $\mathrm{LCCO} 2$ 평가 & 6 개 기준 & $\times$ \\
\hline & 오존파괴물질 사용 금지 & 6 개 기준 & 0 \\
\hline \multirow{3}{*}{$\begin{array}{c}\text { 재료 및 } \\
\text { 자원 }\end{array}$} & 재활용자재 사용 & 6 개 기준 & 0 \\
\hline & 건물 재사용 & 6 개 기준 & 0 \\
\hline & 건설폐기물 관리 & 5 개 기준 & $\times$ \\
\hline \multirow{3}{*}{ 물순환관리 } & 물사용량 절감 & 7개 기준 & 0 \\
\hline & 우수이용 & 6 개 기준 & 0 \\
\hline & 중수도 설치 & 6 개 기준 & $\bigcirc$ \\
\hline 유지관리 & 커미셔닝 & 5 개 기준 & 0 \\
\hline \multirow{5}{*}{ 실내환경 } & 실내공기질 & 7개 기준 & 0 \\
\hline & 자연환기 확보 & 6 개 기준 & 0 \\
\hline & 소음 & 6 개 기준 & 0 \\
\hline & 주광제어 & 5 개 기준 & 0 \\
\hline & 일조 & 5 개 기준 & $\times$ \\
\hline
\end{tabular}

설폐기물 관리, 일조 항목으로 국내기준에의 적용가능성을 검토해 볼 필요가 있다.

\section{$3.2 \mathrm{LCA}$ 평가 관련 항목}

국내외 7개 학교시설 인증기준에서 $\mathrm{LCA}$ 관련 항목을 검토하여 <표 4>에 정리하였다.

$\mathrm{LCA}$ 관련 항목은 항목명에 $\mathrm{LCCO}_{2}$ 혹은 $\mathrm{LCA}$ 를 직접 언급하고 있는 항목을 직접평가항목으로 분류하고, 항목명 에 직접 언급하고 있지는 않으나 $\mathrm{LCCO}_{2}$ 량에 영향을 미치 는 항목을 간접평가항목으로 분류하였다.

직접평가항목은 다시 두 가지 경우로 분류하였다. $\mathrm{LCCO}_{2}$ 량을 시뮬레이션을 통해 직접 산출하거나 산출값을 기준값과 비교하여 절감량을 평가하는 항목과, $\mathrm{LCCO}_{2}$ 량을 직접 산출 하지 않고 $\mathrm{LCCO}_{2}$ 량에 큰 영향을 미치는 요소를 간단히 대체 평가하는 항목으로 구분하였다.

우리나라 기준은 직접평가항목이 없고 자재, 운영에너 지, 수자원, 생태분야에 간접평가하는 항목을 포함하고 있 다. 그 외 모든 외국 인증기준에서는 직접평가항목을 포함 하고 있으며, 운영에너지 및 자재 관련 $\mathrm{LCCO}_{2}$ 량을 평가 하고 있다.
Table 4. LCA items of domestic and foreign green building certification criteria for school

\begin{tabular}{|c|c|c|c|c|}
\hline \multirow{2}{*}{ 분야 } & \multirow{2}{*}{ 평가항목 } & \multicolumn{2}{|c|}{$\begin{array}{l}\mathrm{LCCO}_{2} \\
\text { 직접평가 }\end{array}$} & \multirow{2}{*}{$\begin{array}{c}\mathrm{LCCO}_{2} \\
\text { 간접 } \\
\text { 평가 }\end{array}$} \\
\hline & & $\begin{array}{l}\text { 직접 } \\
\text { 산출 }\end{array}$ & $\begin{array}{l}\text { 대체 } \\
\text { 평가 }\end{array}$ & \\
\hline \multirow{7}{*}{ 우리나라 } & 재료의 탄소배출량 정보 표시 & & & O \\
\hline & 에너지 성능 & & & O \\
\hline & 조명에너지 절약 & & & 0 \\
\hline & 신재생에너지 이용 & & & 0 \\
\hline & 생활용상수절감대책 타당성 & & & O \\
\hline & 우수이용, 중수도 시설 & & & 0 \\
\hline & 생태면적율 & & & 0 \\
\hline \multirow{6}{*}{$\begin{array}{l}\text { LEED } \\
\text { v4 }\end{array}$} & $\begin{array}{l}\text { 건물재사용과 전체 건물 자재 관 } \\
\text { 련 LCA }\end{array}$ & $\mathrm{O}$ & & \\
\hline & 에너지 성능 & & & O \\
\hline & 신재생에너지 이용 & & & O \\
\hline & 물사용량 절감 & & & O \\
\hline & 우수이용 & & & O \\
\hline & 열섬효과 방지 & & & 0 \\
\hline \multirow{7}{*}{$\begin{array}{l}\text { CASBEE } \\
2010\end{array}$} & 시공 관련 $\mathrm{CO}_{2}$ 배출 & & ○ & \\
\hline & 보수, 갱신, 해체 관련 $\mathrm{CO}_{2}$ 배출 & & O & \\
\hline & 운영에너지 관련 $\mathrm{CO}_{2}$ 배출 & $\bigcirc$ & & \\
\hline & 물적약 시스템 & & & 0 \\
\hline & 우수이용, 중수도 시설 & & & O \\
\hline & 생물환경 보전 & & & O \\
\hline & 열섬효과 방지 & & & 0 \\
\hline \multirow{8}{*}{$\begin{array}{l}\text { SBTool } \\
2012\end{array}$} & $\begin{array}{l}\text { 자재의 추출, 제조, 수송 관련 온 } \\
\text { 실가스 배출 }\end{array}$ & $\mathrm{O}$ & & \\
\hline & $\begin{array}{l}\text { 자재의 유지관리, 교체 관련 온실 } \\
\text { 가스 배출 }\end{array}$ & ○ & & \\
\hline & 운영에너지 관련 온실가스 배출 & 0 & & \\
\hline & 교통수단 관련 온실가스 배출 & & 0 & \\
\hline & 물사용량 절감 & & & O \\
\hline & 우수이용, 중수도 시설 & & & O \\
\hline & 탄소제거 관련 식재 & & & O \\
\hline & 열섬효과 방지 & & & ○ \\
\hline \multirow{5}{*}{$\begin{array}{l}\text { BEAM } \\
\text { NB } 1.2\end{array}$} & 건물 구조체의 내재에너지 평가 & $\bigcirc$ & & \\
\hline & 운영에너지 관련 $\mathrm{CO}_{2}$ 배출 & $\bigcirc$ & & \\
\hline & 신재생에너지 이용 & & & O \\
\hline & 물사용량 절감 & & & $\bigcirc$ \\
\hline & 우수이용, 중수도 시설 & & & $\bigcirc$ \\
\hline \multirow{5}{*}{$\begin{array}{c}\text { BREEA } \\
\text { M } \\
2011\end{array}$} & 운영에너지 관련 $\mathrm{CO}_{2}$ 배출 & O & & \\
\hline & 주요 자재 LCA 평가 & $\bigcirc$ & & \\
\hline & 저탄소 기술 & & & $\bigcirc$ \\
\hline & 물사용량 절감 & & & O \\
\hline & 우수이용, 중수도 시설 & & & 0 \\
\hline \multirow{2}{*}{$\begin{array}{l}\text { Green } \\
\text { Star }\end{array}$} & 운영에너지 관련 $\mathrm{CO}_{2}$ 배출 & 0 & & \\
\hline & 물사용량 절감 & & & O \\
\hline
\end{tabular}

$\mathrm{LEED}$ 는 2009버전에는 직접평가하는 항목이 없으나 $\mathrm{v} 4$ 버전에서는 자재 관련 $\mathrm{LCA}$ 평가항목이 포함될 예정이며, 구체적인 평가방법이 제시되지 않아 직접평가항목으로 예 
측하고 검토하였다. CASBEE는 운영에너지 관련 항목은 직접평가항목으로 분류되나 자재 관련 항목은 직접 산출 하지 않고 대체항목으로 평가하고 있다. 자재의 시공 관 련, 보수 - 갱신 - 해체 관련 평가에 대해 구조체 내구연한, 재사용 여부, 재활용자재 사용 여부를 평가하여 $\mathrm{LCCO}_{2}$ 량 과 연계시켜 판단한다.

$\mathrm{SBTool}$ 은 자재와 관련하여 추출-제조·수송과 유지관 리 - 교체로 구분하여 $\mathrm{LCCO}_{2}$ 를 평가하고 있으며, 타 기준 에서는 평가하지 않는 교통수단과 관련하여 개인차량 이 용에 따른 $\mathrm{LCCO}_{2}$ 배출영향을 평가하고 있다.

$\mathrm{BEAM}$ 은 자재와 관련하여 구조체에 대해서만 프로그램 을 이용하여 직접평가하고 있다. 그리고 BREEAM은 운영 에너지와 외벽, 창, 지붕, 슬라브, 내벽, 바닥마감재 등 주 요 자재에 대한 $\mathrm{LCCO}_{2}$ 를 직접평가하고, Green Star는 운 영에너지에 대해서만 직접평가하고 있다.

간접평가항목은 $\mathrm{LCCO}_{2}$ 량을 직접 산출하기는 어려우나 배출량에 영향을 미치는 열섬효과 방지, 저탄소 기술과 같 은 항목과, 수자원 관련 항목, 신재생에너지 이용시설 및 생태환경 등의 탄소상쇄 관련 항목과 같이 $\mathrm{CO}_{2}$ 원단위를 이용하여 산출가능한 항목이 있다.

\section{3 학교시설 관련 특정 평가항목}

국내외 7 개 학교시설 인증기준에서 학교시설 관련 특정 평가항목과 학교급별 구분 여부를 검토하여 <표 5>에 정 리하였다.

학교시설 관련 특정 평가항목은 교육관련, 시설관련, 먼

Table 5. School-related specific items

\begin{tabular}{|c|c|c|c|}
\hline 분야 & 평가분야 & $\begin{array}{c}\text { 학교시설 } \\
\text { 특정 평가항목 }\end{array}$ & $\begin{array}{l}\text { 학교급별 } \\
\text { 구분 여부 }\end{array}$ \\
\hline \multirow{6}{*}{ 우리나라 } & $\begin{array}{l}\text { 에너지 및 } \\
\text { 환경부하 }\end{array}$ & $\begin{array}{c}\text { 운동장 먼지발생 } \\
\text { 방지 }\end{array}$ & \multirow{6}{*}{ - } \\
\hline & 유지관리 & $\begin{array}{l}\text { 보행시에 발생하는 } \\
\text { 먼지배출량 감소 }\end{array}$ & \\
\hline & \multirow{2}{*}{ 생태환경 } & 표토재활용 & \\
\hline & & 생태학습원 조성 & \\
\hline & \multirow{2}{*}{ 실내환경 } & 현휘 감소 & \\
\hline & & 환경교육전용공간 & \\
\hline \multirow{3}{*}{ LEED } & 토지이용 및 & 부지의 마스터플랜 & \multirow{3}{*}{-} \\
\hline & 교통 & 시설의 복합화 & \\
\hline & 기타 & $\begin{array}{c}\text { 학습의 장으로서의 } \\
\text { 학교시설 }\end{array}$ & \\
\hline CASBEE & $\begin{array}{l}\text { 에너지 및 } \\
\text { 환경부하 }\end{array}$ & 모래 및 먼지 & $\begin{array}{c}\text { 초, 중, 고/ } \\
\text { 대학교로 구분하여 } \\
\text { 평가기준 적용 }\end{array}$ \\
\hline Green Star & 유지관리 & 자원에 대한 교육 & - \\
\hline BREEAM & - & - & $\begin{array}{c}\text { 유치원/초, } \\
\text { 중/고등/대학교로 } \\
\text { 구분하여 적용 }\end{array}$ \\
\hline
\end{tabular}

지발생관련 항목으로 분류할 수 있다. 교육 관련 평가항목 은 우리나라, LEED, Green Star 기준에서 포함하고 있고, 먼지발생 관련 평가항목은 우리나라와 CASBEE에서 포함 하고 있다. 시설 관련 평가항목은 $\mathrm{LEED}$ 에서 부지의 마스 터플랜과 시설복합화 관련 항목을 평가하고 있어 국내 기 준의 적용가능성을 검토할 필요가 있다.

그리고 우리나라, LEED, Green Star는 평가기준을 학 교급별로 구분하고 있지 않으나, $\mathrm{CASBEE}$ 는 초·중·고 등학교와 대학교로 구분하여 적용하고 있다. BREEAM은 학교시설 특정 평가항목은 없으나 유치원, 초·중학교, 고 등학교, 대학교로 구분하여 평가기준을 적용하고 있다.

\section{LCA 개념을 도입한 학교시설 녹색건축 인증 기준 개정안}

\section{$4.1 \mathrm{LCA}$ 개념을 도입한 평가항목 도출}

가) LCA 평가범위 및 적용방법 설정

$\mathrm{LCA}$ 의 평가범위는 각 연구의 목적에 따라 다소 다르게

Table 6. Items of building $\mathrm{LCCO}_{2}$ assessment system

\begin{tabular}{|c|c|c|c|c|c|c|}
\hline & & & & 전문가으 & 이견내역 & 평가 \\
\hline & 단계 구분 & & 평가 대상 & $\begin{array}{l}\text { A자문 } \\
\text { 위원 }\end{array}$ & $\begin{array}{l}\text { A자문 } \\
\text { 위원 }\end{array}$ & $\begin{array}{l}\text { 항목 } \\
\text { 검토 }\end{array}$ \\
\hline $\begin{array}{l}\text { 생산 } \\
\text { 단계 }\end{array}$ & 건축자재 & 생산과정 & 내재온실가스 & 필수 & 필수 & 0 \\
\hline 계획 & 건축자재 & 운송과정 & 에너지 & 필수 & $\begin{array}{c}\text { 필수/고려 } \\
\text { 가능 }\end{array}$ & 0 \\
\hline 시공 & 건축물 & 현장 & 에너지 & 필수 & $\begin{array}{c}\text { 필수/고려 } \\
\text { 가능 }\end{array}$ & 0 \\
\hline & & 폐기물 & 에너지 & 필수 & 부적합 & $\Delta$ \\
\hline & 에너지 사 & 사용과정 & 에너지 & 필수 & 필수 & O \\
\hline & 건축물 & 상수 & 에너지 & 필수 & 고려가능 & $\Delta$ \\
\hline & 수자원 & 오수 & 에너지 & 필수 & 부적합 & $\Delta$ \\
\hline & 사용과정 & 중수 & 에너지 & 부적합 & 부적합 & - \\
\hline 사용 & 생활폐기들 & 물 발생량 & 에너지 & 부적합 & 부적합 & - \\
\hline 단계 & 보수자재 & 생산과정 & 내재온실가스 & 필수 & 필수 & 0 \\
\hline & 보수자재 & 운송과정 & 에너지 & 필수 & $\begin{array}{c}\text { 필수/고려 } \\
\text { 가능 }\end{array}$ & $\boldsymbol{\Delta}$ \\
\hline & 건축물 우 & 우지보수 & 에너지 & 필수 & $\begin{array}{c}\text { 필수/고려 } \\
\text { 가능 }\end{array}$ & $\Delta$ \\
\hline & 건축물 후 & 채체과정 & 에너지 & 필수 & 필수 & O \\
\hline & 폐기물 은 & 온송과정 & 에너지 & 필수 & 필수 & O \\
\hline 폐기 & 폐기물 충 & 중간처리 & 에너지 & 고려가능 & 필수 & 0 \\
\hline 단계 & 폐기물 ㅁ & 개립과정 & 에너지 & 필수 & 필수 & O \\
\hline & 폐기 & 소ㄱㅏㅏ & 에너지 & 필수 & 부적합 & $\Delta$ \\
\hline & & & 소각가스 & 필수 & 부적합 & $\Delta$ \\
\hline 탄소 & 신재생 & 에너지 & 에너지생산 & 필수 & 필수 & O \\
\hline 상쇄 & 수 & & 온실가스흡수 & 고려 가능 & 부적합 & - \\
\hline
\end{tabular}


$\mathrm{LCA}$ 개념을 도입한 학교시설 녹색건축인증기준 개선방향에 관한 연구

Table 7. Percentage of $\mathrm{CO}_{2}$ emissions by step for school

\begin{tabular}{c|c|c|c|c}
\hline $\mathrm{CO}_{2}$ 배출 비율 & 건설단계 & 운영단계 & 철거단계 & 합계 \\
\hline 평균 & $24.73 \%$ & $75.26 \%$ & $0.01 \%$ & $100 \%$ \\
\hline
\end{tabular}

Table 8. The scope of Life cycle assessment

\begin{tabular}{|c|c|c|c|c|}
\hline \multicolumn{3}{|c|}{ 평가단계 } & 평가내용 & $\begin{array}{l}\text { LCA } \\
\text { 평가 }\end{array}$ \\
\hline \multirow{3}{*}{ 건설 } & 건축자지 & 생산단계 & 자재사용량 & 0 \\
\hline & 건축자지 & 운송단계 & 운송에너지 & $x$ \\
\hline & 건축자지 & 시공단계 & 시공에너지 & $x$ \\
\hline \multirow{7}{*}{ 사용 } & 에너지 & 가용과정 & 운영에너지 & O \\
\hline & 수자원 & 가용과정 & 수자원 사용량 & O \\
\hline & 생활폐기 & 발생과정 & 생활폐기물 발생량 & O \\
\hline & \multirow{3}{*}{ 유지관리 } & 자재생산 & 자재사용량 & 0 \\
\hline & & 자재운송 & 운송에너지 & $x$ \\
\hline & & 자재시공 & 시공에너지 & $x$ \\
\hline & \multicolumn{2}{|c|}{ 탄소상쇄 } & 신재생에너지, 수목 & 0 \\
\hline 철거 & \multicolumn{2}{|c|}{ 해체/폐기단계 } & 해체폐기에너지사용량 & $x$ \\
\hline
\end{tabular}

설정될 수 있는데 본 연구에서는 국토교통부 연구과제(녹 색건축물 활성화를 위한 온실가스 배출량 평가 및 통합인 증시스템 구축)를 통해 한양대학교에서 개발 중인 건축물 전과정 온실가스 평가·관리 프로그램의 평가범위를 기반 으로 하여 녹색건축인증에서의 평가필요성을 고려하여 설 정하도록 하였다.

현재 개발 중인 건축물 전과정 온실가스 평가- 관리 프 로그램에서는 각 단계별로 아래 표와 같이 평가항목설정 을 고려하고 있다.

건축물의 전생애과정의 온실가스 배출량 평가는 가능한 많은 배출요소를 평가하는 것이 바람직할 것이나 녹색건 축인증의 주요한 취지 중 하나인 평가용이성을 고려할 때 녹색건축인증제도에서 탄소배출과 관련된 모든 대상에 대 해 평가하도록 하는 것은 매우 어렵다고 할 수 있다.

자재생산단계에 비해 자재 운송단계나 시공단계의 에너 지 사용량 등은 $\mathrm{LCA}$ 에서 차지하는 비중이 상대적으로 매 우 작으며(운송, 시공단계에너지 $0.9 \%$, 해체폐기단계 $0.03 \%$ 등) 7$)$ 자재사용량이나 건물의 규모에 따라 달라지는 요소라고 할 수 있을 것이므로 자재사용량과 관련된 평가 를 통해 간접평가하는 것이 바람직할 수 있다.

<표 7>은 초, 중, 고등학교의 단계별 $\mathrm{CO}_{2}$ 배출량 평균비 율을 나타낸 것으로 8$)$, 운영단계가 약 $75.26 \%$ 로 대부분을 차지하고 있고 철거단계는 약 $0.01 \%$ 로 적은 비중을 차지하

7) 이강희, 공동주택의 라이프사이클에너지와 이산화탄소추정에 관한연구, 한국주거학회논문집 제9권4호, 2008, p.89-96

8) 이호진, 행복도시 미래형 선진 학교모델 개발 및 09년 착수 9 개교 RFP 수립 연구용역, 2009, p.221.
Table 9. Main materials emitting $\mathrm{CO}_{2}$ for office

\begin{tabular}{c|c|c|c}
\hline 구분 & 레미콘 & 철강재 & 철근 \\
\hline $\mathrm{A}$ 사무소 건물 & $57.9 \%$ & $14.8 \%$ & $7.89 \%$ \\
\hline $\mathrm{B}$ 사무소 건물 & $57.16 \%$ & $18.41 \%$ & $14.1 \%$ \\
\hline
\end{tabular}

Table 10. LCA result for $S$ city hall(40years life cycle)

\begin{tabular}{|c|c|c|c|c|c|}
\hline & 구분 & \multicolumn{2}{|c|}{$\mathrm{CO}_{2}$ 배출량 $\left(\mathrm{tCO}_{2}\right)$} & \multicolumn{2}{|c|}{ 비율 } \\
\hline \multicolumn{2}{|c|}{ 에너지 소비(신재생 고려) } & \multicolumn{2}{|c|}{196,188} & \multicolumn{2}{|c|}{$74.3 \%$} \\
\hline \multicolumn{2}{|c|}{ 자재 생산, 시공 } & \multicolumn{2}{|c|}{58,145} & \multicolumn{2}{|c|}{$22.1 \%$} \\
\hline \multirow{2}{*}{ 폐기물 } & 생활폐기물 & 2,082 & \multirow{2}{*}{5,378} & $0.8 \%$ & \multirow{2}{*}{$2.0 \%$} \\
\hline & 시공, 해체폐기물 & 3,296 & & $1.2 \%$ & \\
\hline \multicolumn{2}{|c|}{ 수자원(상수, 오수, 중수) } & \multicolumn{2}{|c|}{4,311} & \multicolumn{2}{|c|}{$1.7 \%$} \\
\hline \multicolumn{2}{|c|}{ 수목 } & \multicolumn{2}{|c|}{-387} & \multicolumn{2}{|c|}{$-0.1 \%$} \\
\hline & 합계 & \multicolumn{2}{|c|}{263,865} & \multicolumn{2}{|c|}{$100 \%$} \\
\hline
\end{tabular}

고 있어 철거단계를 별도로 평가하지 않아도 큰 무리가 없는 것으로 판단된다.

따라서 본 연구에서는 개발 중인 온실가스평가관리프로 그램의 평가항목과 기존 연구에서의 분야별 탄소배출비율 을 고려하여 아래<표 8>과 같이 평가단계별로 LCA평가 범위를 설정하도록 한다.

또한 자재 관련 평가시 수많은 건축자재 모두에 대한 정보수집이 어려우므로 비중을 많이 차지하는 주요 자재 를 대상으로 하고자 한다. 사례연구에 의하면 3개 정도의 재료가 전체의 $80 \%$ 이상의 비중을 차지하고 있으며9), <표 9>는 주요자재별 탄소배출 비율을 나타낸 것이다.

일본의 CASBEE에서는 자재의 온실가스 배출량을 직접 산출하지 않고 건물재사용, 재활용자재 사용여부를 통해 간접 평가하고 있으며, 영국의 BREEAM에서 주요 자재에 대해서만 평가하고 있다.

운용단계의 에너지 사용량은 현재 시행되는 에너지효율 등급 평가결과를 이용하여 냉방, 난방, 급탕, 조명, 환기별 운영에너지 사용량을 적용하도록 한다.

그리고 수자원과 탄소상쇄 부분의 평가범위를 설정하기 위해 전체 배출량에서 차지하는 비중 및 평가방법을 검토 하였다. <표 10>은 업무용 건축물을 대상으로 LCA평가 를 한 것이다.10)

상수, 오수, 중수를 고려한 수자원에 의한 $\mathrm{LCCO}_{2}$ 는 전 체 배출량의 약 $1.7 \%$ 를 차지하고, 상수사용에 의한 배출 량은 1 인당 탄소배출계수를 이용하여 산출하고 있어 우수,

9) 국토해양부, 한국건설교통기술평가원, 녹색건축물 활성화를 위 한 온실가스배출량 평가 및 통합인증시스템 구축, 2012. 8, p.140.

10) 한양대학교, 녹색건축물 활성화를 위한 온실가스배출량 평가 및 통합인증시스템 구축, 국토해양부 연구용역 워크솝 자료, p.45, 2013. 3. 
이재옥·김성중 · 이상민 · 이승민

중수에 의한 상수 절감량으로 수자원의 $\mathrm{LCCO}_{2}$ 평가가 가 능할 것으로 판단된다. 식재에 의한 탄소상쇄량은 전체 배 출량의 약 $0.1 \%$ 를 차지하고 있어 상대적 비중은 매우 적으 나 열섬효과완화 등의 효과를 고려하여 전체 식재수와 학 교시설의 특성인 운동장의 잔디조성 면적 등을 평가항목 으로 설정하도록 한다.

나) $\mathrm{LCA}$ 평가항목설정

$\mathrm{LCA}$ 평가 관련 항목을 분야별로 정리하면 <표 11>과 같다.

평가항목은 정량평가항목과 비정량평가 항목으로 구분 할 수 있다. 정량평가항목은 환산계수를 통해 탄소배출량 에 대한 정량적 평가가 가능한 항목이라고 할 수 있는 에 너지효율향상, 주요자재평가, 상수(우수·중수)평가 등이며 절수기기사용, 모니터링 등의 항목은 탄소배출량과 관련하 여 정량적으로 평가가 어려우나 관련성이 높은 항목이라 고 할 수 있다. 이러한 정량, 비정량 평가항목의 설정을 통해 건물의 탄소배출과 관련된 전반적 성능 평가가 가능 할 것이다.

Table 11. Items and evaluation method for LCA

\begin{tabular}{|c|c|c|c|}
\hline 분야 & 평가항목 & 정량평가 & 비정량평가 \\
\hline \multirow{4}{*}{$\begin{array}{c}\text { 에너지 및 } \\
\text { 환경부하 }\end{array}$} & 에너지 효율 향상 & 0 & \\
\hline & 계량기 설치 여부 & & O \\
\hline & 열섬효과 방지 & & 0 \\
\hline & 이산화탄소 배출 저감 시스템 & & O \\
\hline \multirow{4}{*}{$\begin{array}{l}\text { 재료 및 } \\
\text { 자원 }\end{array}$} & 주요자재의 LCA평가 & O & \\
\hline & 건축물 수명 & & O \\
\hline & 탄소성적인증자재 사용 & & O \\
\hline & 기존건축물 재사용 & & O \\
\hline \multirow{4}{*}{ 물순환관리 } & 절수기기 사용 & & 0 \\
\hline & 물사용량 모니터링 & & O \\
\hline & 우수이용 & O & \\
\hline & 중수도 시설 & 0 & \\
\hline 생태환경 & 식재 & O & \\
\hline
\end{tabular}

\section{2 기타 개정필요 항목}

기존의 국내 학교시설 인증기준을 대상으로 추가 및 삭 제필요 항목을 검토하여 <표 12>에 정리하였으며, 추가항 목은 대부분의 외국 인증기준에서는 평가하고 있으나 국 내 기준에서 고려하지 않고 있는 항목을 대상으로 검토하 였다. 추가항목으로는 빛공해 저감, 건물의 향, 곰팡이방 지, 혁신적인 디자인 도입, 전문가 참여 항목을 제안하였 다. 건물의 향의 경우 대부분의 외국 기준에서 일조 관련 항목을 평가하고 있고, 국내 기준에서도 공동주택의 경우 채광률로 평가하고 있으나 소형주택의 경우 건물의 향 및
Table 12. Items necessary to revision for school

\begin{tabular}{|c|c|c|c|}
\hline 분야 & 평가항목 & 검토 & 비고 \\
\hline \multirow{2}{*}{$\begin{array}{l}\text { 토지이용 } \\
\text { 및 교통 }\end{array}$} & 빛공해 저감 & 추가 & $\begin{array}{l}\text { 인공조명으로부터 발생하는 } \\
\text { 과도한 빛 반사 방지 }\end{array}$ \\
\hline & 자전거보관소 & 수정 & $\begin{array}{l}\text { 학교급별 평가기준을 구분할 } \\
\text { 필요 있음 }\end{array}$ \\
\hline $\begin{array}{l}\text { 에너지 및 } \\
\text { 환경부하 }\end{array}$ & 에너지 효율 향상 & 수정 & $\begin{array}{l}\text { 에너지효율등급제도 확산에 } \\
\text { 따라 평가결과 반영할 수 있도 } \\
\text { 록 수정 }\end{array}$ \\
\hline $\begin{array}{l}\text { 재료 및 } \\
\text { 자원 }\end{array}$ & $\begin{array}{c}\text { 화장실에서 } \\
\text { 사용되는 소비재 } \\
\text { 절약 }\end{array}$ & 삭제 & $\begin{array}{l}\text { 학교시설 } 211 \text { 건 통계결과 배점 } \\
\text { 에 대한 획득점수 비율이 약 } \\
98 \% \text { 로 대부분이 점수를 획득 } \\
\text { 하고 있어 평가실효성 낮음 }\end{array}$ \\
\hline \multirow[t]{2}{*}{ 생태환경 } & 표토재활용율 & 삭제 & $\begin{array}{l}\text { 현재 국내에서는 학교시설에 } \\
\text { 만 적용되는 평가항목이나 학 } \\
\text { 교시설의 특성이 반영된 특정 } \\
\text { 항목으로 볼 수 없으며, 학교 } \\
\text { 시설 } 211 \text { 건 통계결과 득점비율 } \\
\text { 이 약 } 2.9 \% \text { 로 평가실효성 낮음 }\end{array}$ \\
\hline & 생태학습원 & 수정 & $\begin{array}{l}\text { 대학교의 경우 실효성이 낮으 } \\
\text { 므로 학교급별 평가기준을 구 } \\
\text { 분할 필요 있음 }\end{array}$ \\
\hline \multirow{3}{*}{ 실내환경 } & $\begin{array}{c}\text { 건축자재로부터 } \\
\text { 배출되는 그 밖의 } \\
\text { 유해물질 억제 }\end{array}$ & 삭제 & 기존 법률에서 제한하고 있음 \\
\hline & 건물의 향 & 추가 & $\begin{array}{l}\text { 일조평가와 관련하여 남향 배 } \\
\text { 치 권장 }\end{array}$ \\
\hline & 곰팡이 방지 & 추가 & $\begin{array}{l}\text { 절적한 계획 및 시공방법을 통 } \\
\text { 해 곰팡이 발생 방지 }\end{array}$ \\
\hline \multirow{2}{*}{ 혁신성 } & $\begin{array}{l}\text { 혁신적인 디자인 } \\
\text { 도입 }\end{array}$ & 추가 & $\begin{array}{l}\text { 혁신적인 기술 및 디자인 도입 } \\
\text { 시 가산점 부여 }\end{array}$ \\
\hline & 전문가 참여 & 추가 & $\begin{array}{l}\text { 녹색건축 전문가 참여시 가산 } \\
\text { 점 부여 }\end{array}$ \\
\hline
\end{tabular}

남향의 창면적으로 평가하고 있어 소형주택 기준을 적용 하였다. 그리고 혁신적인 디자인 도입 및 전문가 참여에 의한 가산항목을 추가하였다.

삭제항목은 화장실에서 사용되는 소비재 절약, 표토재활 용율, 건축자재로부터 배출되는 그 밖의 유해물질 억제 항 목으로 기존의 법률에서 제한하고 있거나 점수획득비율이 너무 높거나 낮아 평가실효성이 낮은 항목들이다.

그리고 수정항목은 에너지효율향상, 자전거보관소, 생태 학습원 항목으로, 에너지효율향상의 경우 에너지효율등급 평가결과 반영할 수 있도록 수정이 필요하며, 생태학습원 과 자전거보관소는 학교급별로 기준을 구분하여 적용할 필요가 있다.

\section{$4.3 \mathrm{LCA}$ 개념을 도입한 학교시설 인증기준 평가항목 개정안 도출}

$\mathrm{LCA}$ 개념을 도입한 학교시설 평가항목 개정안을 도출하 면 <표 13>과 같다.

LCA개념 도입한 학교시설 인증기준은 현재 운영중인 
Table 13. Amendment of green building certification criteria for school

\begin{tabular}{|c|c|c|c|c|c|}
\hline \multirow{2}{*}{ 분야 } & \multirow{2}{*}{\multicolumn{2}{|c|}{ 평가항목 }} & \multicolumn{2}{|c|}{$\begin{array}{c}\mathrm{LCA} \\
\text { 평가항목 }\end{array}$} & \multirow{2}{*}{$\begin{array}{l}\text { 기타 } \\
\text { 평가 } \\
\text { 항목 }\end{array}$} \\
\hline & & & \begin{tabular}{|l|} 
정량 \\
평가
\end{tabular} & $\begin{array}{l}\text { 비정량 } \\
\text { 평가 }\end{array}$ & \\
\hline \multirow{5}{*}{$\begin{array}{c}\text { 토지 } \\
\text { 이용 및 } \\
\text { 교통 } \\
\text { (T) }\end{array}$} & $\mathrm{T} 1$ & 기존대지의 생태학적 가치 & & & 0 \\
\hline & $\mathrm{T} 2$ & 일조권 간섭방지대책의 타당성 & & & 0 \\
\hline & T3 & 대중교통에의 근접성 & & & O \\
\hline & T4 & 자전거보관소 & & & 0 \\
\hline & T5 & 빛공해 저감 & & & O \\
\hline \multirow{9}{*}{$\begin{array}{c}\text { 에너지 } \\
\text { 및 } \\
\text { 환경부 } \\
\text { 하 } \\
\text { (E) }\end{array}$} & E1 & 에너지 효율 향상 & 0 & & \\
\hline & E1 & 계량기 설치 여부 & & $\mathrm{O}$ & \\
\hline & $\mathrm{E} 2$ & 조명에너지 절약 & & & O \\
\hline & E3 & 신재생에너지 이용 & $\mathrm{O}$ & & \\
\hline & $\mathrm{E} 4$ & $\mathrm{LCCO}_{2}$ 배출량 & O & & \\
\hline & $\mathrm{E} 5$ & 열섬효과 & & 0 & \\
\hline & E6 & 이산화탄소 배출저감 시스템 & & O & \\
\hline & E7 & $\begin{array}{l}\text { 오존층보호를 위한 특정물질의 사 } \\
\text { 용금지 }\end{array}$ & & O & \\
\hline & $\mathrm{E} 8$ & $\begin{array}{l}\text { 운동장 먼지발생 방지(잔디조성 운 } \\
\text { 동장일 경우 면적 표기) }\end{array}$ & & & $\bigcirc$ \\
\hline \multirow{7}{*}{$\begin{array}{c}\text { 재료 및 } \\
\text { 자원 } \\
(\mathrm{R})\end{array}$} & $\mathrm{R} 1$ & 유효자원 재활용자재 사용 & & 0 & \\
\hline & $\mathrm{R} 2$ & 재활용 가능자원의 분리수거 & & O & \\
\hline & R3 & 음식물쓰레기 저감 & & $\mathrm{O}$ & \\
\hline & $\mathrm{R} 4$ & 탄소성적인증자재 사용 & & $\bigcirc$ & \\
\hline & $\mathrm{R} 5$ & 기존건축물의 재사용 & & O & \\
\hline & $\mathrm{R} 6$ & 건축물 수명 & & O & \\
\hline & $\mathrm{R} 7$ & 주요자재의 LCA평가 & O & & \\
\hline \multirow{5}{*}{$\begin{array}{c}\text { 물순환 } \\
\text { 관리 } \\
(\mathrm{W})\end{array}$} & W1 & 우수부하 절감대책의 타당성 & & & $\bigcirc$ \\
\hline & $\mathrm{W} 2$ & 생활용 상수절감대책의 타당성 & & 0 & \\
\hline & W3 & 우수이용 & O & & \\
\hline & W4 & 중수도 시설 & 0 & & \\
\hline & W5 & 수자원 모니터링 & & $\bigcirc$ & \\
\hline \multirow{4}{*}{$\begin{array}{l}\text { 유지 } \\
\text { 관리 } \\
(\mathrm{M})\end{array}$} & M1 & $\begin{array}{l}\text { 환경을 고려한 현장관리계획의 합 } \\
\text { 리성 }\end{array}$ & & & $\bigcirc$ \\
\hline & M2 & 운영/유지관리 매뉴얼 제공 & & & O \\
\hline & M3 & 커미셔닝 & & & O \\
\hline & M4 & 보행시 발생하는 먼지배출량 감소 & & & 0 \\
\hline \multirow{6}{*}{$\begin{array}{l}\text { 생태 } \\
\text { 환경 } \\
(\mathrm{G})\end{array}$} & G1 & 연계된 녹지축 조성 & & & $\bigcirc$ \\
\hline & G2 & 자연지반 녹지율 & & & 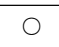 \\
\hline & G3 & 생태면적율 & & & $\bigcirc$ \\
\hline & G4 & 비오톱 조성 & & & $\mathrm{O}$ \\
\hline & G5 & 생태학습원 조성 & & & $\bigcirc$ \\
\hline & G6 & 식재수 & 0 & & \\
\hline \multirow{8}{*}{$\begin{array}{l}\text { 실내 } \\
\text { 환경 } \\
(\mathrm{Q})\end{array}$} & Q1 & 실내공기오염물질 저방출 자재의 사용 & & & $\bigcirc$ \\
\hline & Q2 & 자연환기성능 확보여부 & & & $\bigcirc$ \\
\hline & Q3 & $\begin{array}{l}\text { 적정 열원기기 배치 및 실내자동온 } \\
\text { 도조절장치 채택 }\end{array}$ & & & $\bigcirc$ \\
\hline & Q4 & 소음 & & & 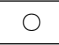 \\
\hline & Q5 & 현휘감소 & & & O \\
\hline & Q6 & 휴식 및 재충전을 위한 공간 & & & $\bigcirc$ \\
\hline & Q7 & 건물의 향 & & & O \\
\hline & Q8 & 곰팡이 방지 & & & O \\
\hline \multirow{2}{*}{$\begin{array}{c}\text { 혁신성 } \\
\text { (I) }\end{array}$} & I1 & 혁신적인 디자인 도입 & & & O \\
\hline & $\mathrm{I} 2$ & 전문가 참여 & & & $\mathrm{O}$ \\
\hline
\end{tabular}

녹색건축인증제도의 평가항목을 기반으로 전체 8 개 평가 분야, 44 개 평가항목으로 구성하였다. 기존의 학교시설 평 가항목에서 $\mathrm{LCCO}_{2}$ 관련 5 개 항목과 기타 학교시설 용도 특성을 고려해 추가가 필요한 것으로 검토된 6개 항목을 추가하였으며 법률상 이미 제한하고 있거나 점수획득율이 너무 높거나 낮아 평가실효성이 낮은 3개 항목을 삭제하 여 구성하였다.

$\mathrm{LCA}$ 평가항목을 통해 생애주기동안의 $\mathrm{LCCO}_{2}$ 배출량에 대한 정확한 평가를 하는 것은 불가능하나 제안된 $\mathrm{LCA}$ 와 관련된 평가항목의 설정을 통해 대상건물의 LCA와 관련 된 녹색건축성능의 상당부분을 평가할 수 있을 것이다. 추 후 인증평가 분야 및 평가항목에 대한 가중치 설정시 정 량적 평가항목을 중심으로 학교건물의 배출비율 자료 등 을 기반으로 전문가 $\mathrm{AHP}$ 조사 등을 통해 가능한 학교건물 의 $\mathrm{LCCO}_{2}$ 배출량과 연계를 가지도록 가중치를 설계하는 것이 바람직할 것으로 판단된다.

\section{5. 결론}

건축물의 에너지 소비량 및 이산화탄소 배출 절감은 전 세계가 당면한 과제이며 건축물의 운영주기 뿐만 아니라 생산, 시공, 운영, 폐기의 전생애주기를 고려하고 있다.

우리나라는 2013년 2월 23일을 기준으로 녹색건축물 조 성 지원법이 시행되어 건축물의 녹색화에 새로운 시도를 하면서 녹색건축 인증기준도 전반적인 개정작업을 시작하 였으나, 전생애주기를 고려한 LCA개념이 반영되지 못하 고 있다.

본 연구에서는 국내외 녹색건축 인증제도 및 평가항목 의 비교, 분석을 통해 LCA개념을 도입한 학교시설 녹색 건축인증기준의 개정방향을 모색하되, LCA 개략평가가 가능한 방법을 제안하고자 한다.

국내외 7 개 녹색건축 인증기준을 비교분석하면 우리나 라를 제외한 6 개 외국 인증기준에서는 $\mathrm{LCA}$ 평가항목을 적용하고 있다. 대부분 운영에너지와 자재 관련 $\mathrm{LCA}$ 를 평가하고 있으며 LCA 평가프로그램을 이용하여 배출량을 산출하거나 산출된 값을 기준값과 비교하여 절감량을 평 가한다. 그리고 $\mathrm{CASBEE}$ 의 경우는 배출량을 직접 산출하 지 않고 구조체 내구연한, 기존건물 재사용, 재활용자재 사용여부와 같이 대체항목에 의해 간략히 평가하고 있다.

본 연구에서는 $\mathrm{LCA}$ 와 관련한 평가항목을 학교시설의 특성을 고려하여 필요한 항목을 검토하였다.

LCA 개념을 도입한 학교시설 녹색건축인증기준의 평가 
항목 개정안을 제안하면 다음과 같다.

- 녹색건축인증에서 $\mathrm{LCA}$ 와 관련된 모든 평가항목을 도 출하여 평가하는 것은 현실적으로 불가능하므로 평가 비중이 크고 건물간의 상대적인 평가대상으로서의 가 치가 있는 평가항목인 자재사용량, 수자원사용량, 에 너지사용량, 환경오염배출량과 관련된 평가항목을 설 정하도록 한다.

- LCA평가와 관련된 항목은 정량적으로 평가가 가능한 $\mathrm{LCA}$ 관련 평가항목과 정량적으로 평가가 어려운 $\mathrm{LCA}$ 관련 평가항목, $\mathrm{LCA}$ 와 관련이 없는 평가항목으로 구 분할 수 있는데 학교시설 녹색건축평가를 위해서는 이들 대상항목을 모두 포함하도록 한다.

- LCA평가와 관련된 정량적으로 평가가 가능한 항목으 로 에너지효율성능, 자재사용량, 우수사용량 등을 설 정하였다.

- 정량적으로 평가가 어려우나 평가가 필요한 $\mathrm{LCA}$ 관련 평가항목으로는 생활용상수절감대책, 계량기설치여부, 열섬효과, 이산화탄소 배출저감 시스템, 탄소성적인증 자재 사용 등의 평가항목을 설정하였다.

- LCA평가와 직접 관련은 없으나 학교시설의 용도특성 과 관련하여 중요하게 고려할 필요가 있는 건물의 향, 곰팡이 방지, 생태학습원, 환경교육공간 등의 평가항 목을 설정하였다.

본 연구는 $\mathrm{LCA}$ 와 관련하여 학교시설에서 평가가 필요한 항목설정에 대한 기초연구이며 향후 건축물전과정온실가스 평가관리프로그램 개발연구와 연계하여 평가항목 및 가중 치 설정에 대한 연구를 진행하며 $\mathrm{AHP}$ 분석기법 등을 통해 분야별 전문가의 의견을 적극 반영하도록 할 예정이다.

\section{참고문헌}

1. Nam Jung-Kul, Educational administration and Management, Kyoyookbook, 2012.

2. LEE Ho-Chin, School of architecture planning, Korea Institute of Educational Environment, 2009.

3. Kim Tae-Young and 1 other, A fundamental study on the LCA assessment of reinforced concrete buildings, Journal of the Architectural Institute of Korea, 2009.4

4. Multi-functional Administrative City Construction Agency, Multi-functional Administrative City school model development of future advanced and establishment of a research project launched in September, 09 schools RFP, 2009.12
5. Kim Yoon-Duk and 3 others, Eco-friendly construction technology evaluation methods by integrated analysis of LCC-LCA, Korea Institute of Construction Engineering and Management, 2011.5

6. Cha Ki-Uk, Calculate $\mathrm{CO}_{2}$ emissions and environmental costs study for different types of construction waste calculated by the LCA-based, Master's thesis of Graduate School of Kyungpook National University, 2011.

7. Hong Tae-Hoon and 2 others, Environmental impact assessment method for buildings using Life Cycle Assessment (LCA), Korea Institute of Construction Engineering and Management, 2012. 9.

8. BRE, BREEAM 2011 NEW CONSTRUCTION, 2011.

9. JSBC, CASBEE for New Construction Assessment Manual(2010 Edition), 2011.

10. USGBC, LEED2009 for NEW CONSTRUCTION \& MAJOR RENOVATIONS, 2011.

11. http://www.breeam.org/

12. http://www.gbca.org.au/

13. http://www.ibec.or.jp/CASBEE/

14. http://www.usgbc.org/

15. http://www.beamsociety.org.hk/en_index.php

접수 2013. 4. 4

1차 심사완료 2013. 4. 26 게재확정 2013. 5. 20 